\section{NU UNA Kastamonu Eğitim Dergisi Kastamonu Education Journal}

Ocak 2019 Cilt:27 Sayı:1

kefdergi.kastamonu.edu.tr
Başvuru Tarihi/Received: 16.06.2017

Kabul Tarihi/Accepted: 16.04 .2018

DOI: 10.24106/kefdergi.417776

Okul Yönetişimi Ölçeği’nin Psikometrik Analizi ve Okul Müdürü, Öğretmen ve Okuldaki Diğer Personel Üzerine Bir Uygulama

\title{
Psychometric Analyses of the School Governance Scale and a Study for Principals, Teachers and Other School Personnel
}

\section{Öz}

\author{
Bahar Meral ŞAHIN ${ }^{1}$, Gökhan ARASTAMAN²
}

Bu araştırmanın temel amacı kamu okullarında görev yapan yönetici, öğretmen ve diğer okul personelin görüşlerine dayalı olarak geçerli ve güvenilir bir okul yönetişimi ölçeği geliştirmektir. Araştırma birbirini takip eden iki aşamada yürütülmüştür. Araştırmanın ilk aşamasında Okul Yönetişimi Ölçeği'nin (OYÖ) geçerlik ve güvenirlik değerleri, 217 yönetici, öğretmen ve diğer personelden toplanan veriler üzerinde Açımlayıcı Faktör Analizi (AFA) ve Cronbach alfa katsayısı ile incelenmiş ve OYÖ’nün geçerli ve güvenilir bir ölçek olduğu görülmüştür. Araştırmanın ikinci aşamasında ise yönetici, öğretmen ve diğer personelin okul yönetişimini benimseme düzeyinin görev, cinsiyet ve kıdem değişkenleri bakımından fark gösterip göstermediği OYÖ’nün 322 yönetici, öğretmen ve diğer personele uygulanmasıyla incelenmiştir. İkinci aşamadan elde edilen sonuçlara göre katılımcıların okul yönetişimini benimseme düzeyinde görev ve cinsiyet değişkeni bakımından anlamlı farklılaşmalar olduğu, kıdem değişkenine göre ise anlamlı farklılaşmanın olmadığı gözlenmiştir.

Anahtar Kelimeler: Yönetişim, yönetim, okul yönetişimi, okul personeli, okul müdürü, öğretmen

\section{Abstract}

The main objective of this study is to develop a valid and reliable school governance scale based on the views of principals, teachers and other school personnel in public schools. The study was conducted in two subsequent phases. Initially by using the data gathered from 217 principals, teachers and other school personnel, the validity and reliability of the "School Governance Scale- SGS" were ensured via exploratory factor analyses (EFA) and Cronbach's alpha coefficient. In this case the instrument was found to be valid and reliable. In the second phase of the study, whether the school governance perception of principals, teachers and other personnel were differentiated according to their gender, seniority and task were analyzed by conducting SGS to 322 participants. According to the results, obtained from the second phase, it was found that the participant's school governance differed significantly in terms of task and gender, and there is no significant difference in terms of seniority

Keywords: Governance, government, school governance, school personnel, school principal, teacher 


\section{Extended Summary}

Introduction. Globalisation, economical\&technological advances and in tandem with these advances, getting closer of people and communities around the world, who are unaware of each other, have made change a must. Today, new concepts concerning democracy and goverment system have been put forward and have been a matter of debate. Governance is one of these concepts (Toksöz, 2008) Being frequently mentioned and researched in reviews recently, the term "governance" goes not only for the private organisations but also for governmental organisations (Bevir, 2013). However, it constitutes hard and sophisticated stages to transfer sub-components of the term "governance" into practice and thus into education. It is hard to bring realm of political economy into conformity with advantage of differing partners. (Lewis and Petterson, 2009).

Governance meaning "to lead and to decide" derives from "Guberne" in Latin. Original form of the word means "to act together to reach the goal". The word "gouvernance" used as "the art of leading" in 13th century settled into English as "Governance" (Ergün, 2006). To define the formal institutions of the state and their legitimate coervice power, Anglo-American political theory uses the word "government".

Governance is a multi-meaning umbrella concept with various uses. Thefore, it can be defined as a context-based term. Historically, it can be seen that the terms "government" and "governance" have been used alternately in order to define the role of the state which governs the community from the centre (Koiman, 1993; Rhodes, 2007). However, it can be said that there is a concensus on the need to improve management styles which blurs the borders between private and state sectors. (Rhodes, 1996; Stoker, 1997).

Governance, which emerged as a new way of government in the 21st century, has come to the fore as conventional systems lost their function and caused deficiencies in providing services. Governance is seen to gain importance as a result of the assumption that conventional management systems are no longer able to be efficiently functioning. (Özer, 2015)

At present, more than one authority is to involve in the process of decision making and execution mechanisms in public sectors, and many organisations, institutions, private persons or legal identities representing national or international community are party to government besides governmental organisations. (Tekeli, 1996). Therefore, it doesn't seem possible to meet the changes in every field with a government system of previous century (Bozkuş, 2009). Changes in different fields may cause changes in another unpredicted field. There now appears to be a need to manage the phenomenon "change" itself. Regarded as the contemporary form of government, governance suggests a "local, transparent, participative, work-allocated and cooperative" government way forcing the "centralized, unitary, bureaucratic, hierarchical" government way of 20th century to transform (Toksöz, 2008).

In order to improve the quality of school management, it is very important that employees take over responsibility, cooperate with each other and actively engage in the administration. For a renovation of educational system and improvement of school governance, it is essential that the overall school personnel and educational agents be trained about "administration of educational systems". In this context, in the efforts to make schools more efficiently-governable, the term "governance" tends to gain more common ground.

School governance has its roots in the idea that "public systems can't be managed with a top-down process on the basis of linear processes. Emergence of the term "governance" in education is a result of a paradigm switch which can be summarised as a transition from a mono-agent linear administration to interactive common activities of differing groups or agents. (Altrichter ve Merki, 2010). School governance has many working networks, and roles and interests of participating agents vary. Working networks of school governance are so broad since responsibilities and expectations in a school environment is so high. Governors are the main agents of school governance, and they are right at the heart of this multi-branch working network. Hence, governors in governance don't act isolatedly on their own; instead, not only within their schools but also with the other schools do they interact.

Purpose. The main purpose of this study is to introduce a reliable and valid scale which measures school governance adoption levels of school principals, teachers and other personnel in public schools. Second purpose is to examine whether school governance adoption levels of school principals, teachers and other personnel differ in terms of position, gender and seniority.

Method. In this two-stage study, firstly realiability and validity of SGS was studied. In the second stage, whether school governance adoption levels of the participants have statistically significant difference in terms of seniority, position and gender was analyzed by conducting latest reliable and valid version of SGS to new participants who hadn't been involved in the initial group. Fort he pilot study which aimed to ensure validity and reliability was put into practice on 217 principals, teachers and other personnel who were already employed at public schools in Aksaray in 2016-2017 educational year. In the study, personal information form and SGS, which had been developed by the researchers, were utilised for data gathering. For measuring structural validity of the scale and finalizing the

| Kastamonu Eğitim Dergisi, 27(1), 2019| 
scale, EFA (Explatory Factor Analysis) was used. For EFA and other statistics, SPSS 20.0 was used. EFA resulted in 36 items and three sub-dimensions as "Justice and Transparency", "Cooperation and Participation" and "Relations with the environment".

In the 2nd stage of the study, adoption levels of principals, teachers and other personnel were studied in terms of demographic variables. This stage of the study was designed in accordance with the survey model. Data obtained at this level were analyzed using quantitative techniques. Sample of the study consisted of 322 principals, teachers and other personnel working at public schools in the city centre of Aksaray. Participants of the first stage were not involved in the second stage. For analysis of the data; descriptive statistics such as arithmetic mean and standard deviation and parametric analysis (T-test, ANOVA) were utilised.

By using T-test, principals', teachers' and other personnels' perception of governance over gender was found to be significant. By using ANOVA (One-way variance analysis); principals', teachers' and other personnels' perception of governance over position and seniority was found to be significant. Findings. In all sub-dimensions of SGS, school governance adoption levels of school principals are higher than that of teachers and other personnel. In the dimension of "Justice and Transparency", there was a meaningful difference between school governance adoption levels in the "position" variable. School governance adoption level of male participants (mean. 4,17) was higher than that of female participants (mean 3,97). School governance adoption levels of the participants had meaningful significance in the "seniority" variable.

Discussion. With this study, it was aimed to introduce a scale which could identify school governance adoption levels of school principals, teachers and other personnel. At the first stage of this 2-stage study, it was deduced that SGS was practical for measuring school governance adoption levels of principals, teachers and other personnel of schools in Turkey, and was a valid and reliable measuring scale consisting of 3 sub-dimensions and 36 items.

At the second stage of the study, SGS, which had been maintained reliable and valid, was analyzed on a different participating group over some demographic variables. Considering school governance adoption levels of totally 322 principals, teachers and other personnel, participants were found to have relatively higher adoption levels in "relations with the environment" sub-dimension (Municipalties, headmen, NGOs, other public and private organisations around the school area). This finding can be interpreted as there needs to be different participating agents in school administration.

In the study, how the participants' gender effect their perception of governance was also examined, and a meaningful significance was found out in the "relations with the environment" sub-dimension. While school governance adoption levels of males and females were very much alike in the first and second sub-dimensions, it was much higher for the males in the third sub-dimension. This can be explained as a reflection of traditional gender role in the organisations. 


\section{Giriş}

Küreselleşme, ekonomik-teknolojik gelişmeler ve bu gelişmelere bağlı olarak dünyanın farklı yerlerinde birbirinden habersiz yaşayan insanların, toplulukların birbirlerine yakınlaşması, değişimi zorunlu kılmıştı. Bilgiye erişimin oldukça hızlı olması, günümüzde demokrasiye ve yönetim anlayışına ilişkin ortaya çıkan yeni kavramların gündeme gelmesine ve tartışılmasına neden olmaktadır. Yaşanan bu hızı değişim ve dönüşüm sürecinde, yöneten yönetilen ilişkilerinde demokratikleşme ihtiyacı, devletin hizmet sunma kapasitesinin iyileştirilmesi gibi nedenlerle "yönetimi" meşru kılan koşulların yıprandığı, yönetimde yeni arayışların ortaya çıkmaya başladığı, yönetişim kavramının da bunların başında geldiği görülmektedir (Sobacı, 2007; Toksöz, 2008). Vatandaşların her alanda karar alma süreçlerine katımasını ve kamusal hizmetlerin etkili, verimli ve şeffaf bir şekilde yerine getirilmesini vaat eden yönetişim, yönetimde yeni bir sürece işaret etmektedir (Sobacı, 2007). Son yıllarda alanyazında sık vurgulanan ve incelenen bir kavram olarak dikkat çeken yönetişim kavramı, yalnızca özel sektördeki örgütler için değil aynı zamanda kamu kesimindeki örgütler için de geçerlidir (Bevir, 2013). Ancak yönetişim kavramının alt bileşenlerini, pratiğe ve dolayısı ile eğitim sistemine aktarmak zor ve karmaşık aşamalar içerir.

"Yönetmek ve karar vermek" anlamlarına gelen "yönetişim" Latincedeki "guberne" kelimesinden türetilmiştir. Kelimenin özgün hali "hedefe ulaşmada birlikte hareket etmeyi" ifade etmektedir. 13. yüzyılda "yönetme sanat" anlamında kullanılan "gouvernance" İngilizceye "governance" olarak geçmiştir (Ergün, 2006). Yönetişim çok farklı kullanımları olan, çok yönlü şemsiye bir kavramdır. Bu yüzden yönetişim bağlam-bağımlı bir kavram olarak nitelendirilebilir. Tarihsel olarak bakıldığında yönetme (government) ve yönetişim (governance) kavramlarının, toplumu merkezden yöneten devletin rolünü tanımlamak için birbirinin yerine geçecek şekilde kullanıldığı görülmektedir (Koiman, 1993; Rhodes, 2007). Ancak yönetişim kavramının gelişmesiyle birlikte kamu ve özel sektör arasındaki farklılıkların azaltacak yönetim yaklaşımlarının geliştiğinden bahsedilebilir (Rhodes, 1996; Stoker, 2004).

\section{Yönetimden Yönetişime Geçiş ve Yönetişimi Gerekli Kılan Faktörler}

Günümüzde kamusal alanın her türlü karar alma ve uygulama mekanizmalarında çok aktörlü bir süreç yaşanmakta; ulusal ve uluslararası toplumu temsil eden pek çok örgüt, kurum, özel ve tüzel kişiler devlet kurumlarının yanında yönetime ortak olmaktadır (Tekeli, 1996). Özellikle 21. yüzyılda yeni bir yönetim anlayışı olarak gelişen yönetişimin, geleneksel sistemlerin işlevselliğini kaybetmesi ve kamu hizmetlerinde aksamaların olması nedeniyle daha fazla gündeme geldiği görülmektedir. Yönetişimin, geleneksel yönetim biçimlerinin çalışma verimliliğini sağlayamadığı varsayımı ile ön plana çıktı̆ı belirtilmektedir (Hodgson, 2001; Özer, 2015). Kooiman (2003) yönetişime olan gerekliliği, kamu yönetiminde tek boyutluluğun ve tekil mücadelenin yetersizliğine dayandırmaktadır. Ona göre yönetimi üstlenen öğelerden hiçbiri karmaşık problemleri çözmek için gerekli donanıma, öngörüye, geniş bilgi birikimine ya da dinamik sorunlarda etkili olacak perspektife tekil olarak sahip olamaz. Yani yönetişim, iletişim ve etkileşim temelli olarak yönetim tarafları arasında yükselen bir ilişkiler ağıdır.

Yönetimden yönetişime geçiş, derin bir toplumsal değişimi ve yönetim mekanizmaları hakkındaki düşüncenin dönüşümünü yansıtmaktadır. Bu değişim ve dönüşüm genel olarak küreselleşme, toplumların demokratikleşmesi, toplumsal yapılardaki artan iç çeşitlilik, bilimsel ve teknolojik gelişmeler, uluslararası kuruluş ve şirketlerin etkisi, kamu işleyişinin yetersiz kalması gibi ana faktörlere atfedilmektedir (Özer, 2015; Bush ve Heystek, 2003;). Halasz (2003) ise eğitim örgütlerinde yönetişimi gerekli kılan faktörleri dışsal faktörler ve bizzat eğitimin iç dinamiklerinden kaynaklanan içsel faktörler şeklinde iki ana kategoride ele almaktadır.

\section{Dışsal Faktörler}

- Yetmişli yılların ortalarından itibaren birçok hükümet tarafindan periyodik olarak takip edilen kısıtlayıcı bütçe politikaları.

- Kalite yönetimi, tüketici memnuniyeti, performans yönetimi, kamu-özel sektör ortaklığı dış kaynak kullanımı gibi hedefleri vurgulayan daha geniş yönetişim ve kamu yönetimi reformları.

- Ulusal, kültürel, dini veya dilsel bakımlardan azınlıkların çeşitli katlımcı, demokratikleşme ve otonomist hareketleri.

- Sosyal, toplumsal ya da ulusal çözümlerin aksine bireycilik, yerelcilik, pazar ekonomisi gibi çözümleri destekleyen ideolojik ve kültürel değişiklikler.

- Artan tüketici farkındalığı ve bireyselleştirilmiş ürünler arayışı ile beraber, sosyal ve tüketici ihtiyaçlarının yüksek düzeyde farklılaşması ve bireyselleştirilmesi.

- Ulusal ekonominin ve toplumsal süreçlerin düzenlenmesinde ulus devletlerin rolünü zayıflatan küreselleşme ve uluslararası entegrasyon. 
- Yerel girişimler ve girişimciliği teşvik eden ulusal ve uluslararası yenilik ve kalkınma politikaları.

- Yeni bilgi ve iletişim teknolojilerinin ortaya çıkışı ve bunların kurumların yönetimi üzerindeki etkisi.

- Kurumsal kalite güvencesi yaklaşımlarını vurgulayan yeni kalite teknik ve politikalarının ortaya çıkması. İçsel Faktörler

- 1960 'ı yıllardan itibaren yapılan eğitim reformlarının zayıf sonuçlarının yarattğı düş kırıklığı.

- Orta ve yükseköğretimin yaygınlaşmasıyla beraber öğrenci nüfusunun artan çeşitliliği.

- Öğretimin profesyonelleşmesi ve öğretmenlerin mesleki özerklik talepleri.

- Proje metodu veya diğer bireyselleştirilmiş öğretim ve öğrenme teknikleri gibi yeni pedagojik teknolojilerin gelişmesi ve yaygınlaşması.

Yukarıda sıralanan faktörler yeni bir yönetim sürecine, yeni bir yönteme atfta bulunarak yönetimin anlamındaki değişmeyi vurgulamaktadır (Rhodes, 1996). Bu sebeple yönetişimin devlette, toplumda ve özel sektörde benimsenmesi de kaçınılmaz olmaktadır. Dolayısıyla belirtilen tüm faktörler birlikte ele alındığında, her alanda yaşanan değişime cevap verebilmenin bir önceki yüzyıldan kalma yönetim anlayışı ile mümkün olamayacağı söylenebilir (Bozkuş, 2009; Memduhoğlu, 2011; Bevir ve Rhodes, 2003).

\section{Okul Yönetişimi}

Okul müdürleri görevlerini yaparken, mevzuat, öğretim programı, aileler, öğrenciler, dış çevre, maddi sorunlar ve sosyoekonomik gelişmeler gibi birçok meydan okuyucu durumla baş etmek durumundadırlar. Bu güçlüklerin birçoğu okul müdürünün kontrolü dışında sürekli olarak değişiklik göstermektedir. Dolayısı ile çok sayıda özerk paydaşın karmaşık etkileşimine dayalı bir ortamda işini yapan müdürler açısından klasik yönetim anlayışı günümüzde bu meydan okuyucular karşııında yetersiz kalmaktadır. Okullar daha açık örgütler haline geldikçe ve farklı karmaşık ihtiyaçlar ve talepler ortaya çıktıkça, "yönetimden" çok yönetişim modelinin bu sorunlara çare olabileceği vurgulanmaktadır (Halasz, 2003; Ünver, Dikbayır ve Yurdakul, 2015; Selwyn, 2016).

Günümüzde internet ve sosyal medya, teknoloji ve uygulamaların yaygınlaşması sonucunda eğitimden ekonomiye, sosyal yaşantidan teknolojiye ve iletişim şekillerine kadar pek çok alanda ciddi değişimler meydana gelmiştir. Okullar da bulundukları çevre ve üstlendikleri işlevler nedeniyle bu değişim sürecine ayak uydurmak durumundadırlar. 21. yüzyılın paradigması olan yönetişim kavramı, son otuz yılda eğitim yönetimini de derinden etkilemeye başlamıştı. Bu yeni yaklaşımla beraber, merkezi bir şekilde eğitim sistemlerinin yönetilmesi yerine yerinden yönetimin önemi vurgulanmaya başlanmıştır. Böylelikle kapalı bir sistem yerine toplumsal gelişime açık bir eğitim sisteminin oluşturulması amaçlanmaktadır (Halasz, 2003). Diğer yandan okulların özerkliğinin artması, okullara ayrılan bütçenin azalması, öğrenci başarısını arttırmaya yönelik sürekli artan baskı ve kurumlar arasındaki işbirliğine sürekli vurgu yapılması gibi tüm dünyada değişen eğitim politikaları yönetişimin kavramının gündeme gelmesine ve tartş̧ımasına neden olmuştur (Altrichter ve Maag Merki, 2010; Showunmi, 2013).

Okul yönetişimi, okulun paydaşları olan öğretmenler, ebeveynler ve diğer topluluk üyeleri arasında karar verme yetkisini paylaşma yeteneğidir. Genel olarak okul yönetişimi (school governance), okul ve çalışanları için kural ve politikaların geliştirilmesi işini yapar. Diğer bir deyişle okulda yönetişim daha çok okulun nasıl yönetileceği konusunda karar alma ile ilgili iken okul yönetimi (government) personel işleri, okul müfredatının hazırlanması gibi okulun günlük çalışmalarıyla ilgilidir. Öğrenciler için en uygun veya ideal bir öğrenme ortamını sağlamak için okullar nasıl yönetilmelidir sorusu, uluslararası eğitim araştırmalarının odak noktasını oluşturmaktadır. Son 30 yılda gelişmiş Batı toplumlarının eğitim sistemlerinde önemli yapısal değişiklikler olmuştur. Bu değişikliklerde okulların daha bağımsız olmaları gerektiğine, eğitimde ademi merkeziyetçiliğe ve geleneksel yöntemlerin dışında farklı yeni yollarla okulları yönetme fikrine vurgu yapıldığı görülmektedir (Darling-Hammond ve Bullmaster, 1997; Lunenburg ve Ornstein, 2013).

Ancak eğitimde yerelleşme ve özerkleşme politikalarının yukarıda tartışıldığı üzere her zaman istenilen sonucu vermeyebileceği yönünde araştırmalar da vardır. Bu çalışmalarda neo-liberal politikalar çerçevesinde okulların yerelleşmesinin belirtilen sorunlara çare olmayacağı, eğitim ve öğretimin niteliğini artırmayacağı, tersine var olan eşitsizliği devam ettireceğini göstermektedir. Devletin yeniden yapılandırılmasını ve kamusal yönünün tasfiye edilmesini öngören neo-liberal politikalar bağlamında düşünüldüğünde eğitimde yerelleşme çalışmalarının beklenilenden öte, karışık ve eşitsizlik üreten bir süreç olduğu görülmektedir. Bu politikalar çerçevesinde okul özerkliği uygulamasının demokrasi ve katıımı sağlamada beklentileri karşılama düzeyi tartışmalıdır (Yolcu, 2010). Yazara göre okul özerkliğinin sonuçlarının en iyi, okulların içinde bulunduğu yakın çevrenin sosyo-ekonomik düzeyi (SED) ile ele alınıp değerlendirilmesi gerekir. Benzer şekilde ailelerin okul yönetimine katıımı da okulun bulunduğu çevrenin SED'ine göre farklılaşmaktadır. Üst SED'de bulunan aileler okul yönetiminde daha çok yer almaktadırlar. Bu çalışmaya göre yönetişimin bir örneği olan okul aile birliği 
modelinde üst SED'deki okullar bütçe dışı kaynak bulmada güçlük çekmemekte ve var olan kaynağı doğrudan eğitimin niteliğini artırmaya yönelik çalışmalara harcamaktadırlar. Tam tersine düşük SED çevrelerinde bulunan okullar ise elde ettikleri bütçe dışı kaynaklarını doğrudan zorunlu işletim giderlerine harcamaktadırlar (Yolcu, 2011).

Okul yönetişimi okullarda tüm paydaşların söz sahibi olmalarını sağlama vaadindedir. Buna göre yönetimden yönetişime geçmek isteyen bir okul sistemi okula ilişkin tüm paydaşların görüş ve önerilerini hesaba katmalı ve bunu okul yönetimine yansıtmalıdır. Yönetişimin sivil toplumu güçlendirerek genişletme iddiasında bulunması ve sivil toplumun tüm aktörlerini karar alma süreçlerine dahil etmesi, katılımcı demokrasi bağlamında değerlendirildiğinde; okul çalışanlarının yönetişim algısını cinsiyet, kıdem ve görev değişkenleri bakımından incelemek önem arz etmektedir. (Gündüz ve Balyer, 2013; Backmen ve Trafford, 2007)

Daha çok kamu yönetimi alanında tartş̧ılan ve uygulanma alanı bulan yönetişimin eğitim örgütleri için ne anlam ifade ettiği ve bu örgütlerde neden yönetişime ihtiyaç duyulduğu konusunda Backmen ve Trafford (2007) ana nedenler olarak etik ve politik nedenler ile toplumun hızla değişmesini göstermektedir. Yazarlara göre eğitim örgütlerinde yönetişim, disiplini ve öğrenmeyi geliştirme, fikir ayrılığını azaltma, okulu daha rekabetçi hale getirme ve demokrasinin geleceğini güvence altına alma bakımlarından eğitimde yaşanan sounlara çare olabilir.

\section{Araştırmanın Amacı}

Bu araştırmanın ana amacı kamu okullarında görev yapan yönetici, öğretmen ve diğer personelin okul yönetişimi algısını ölçen geçerli ve güvenilir bir ölçek geliştirmektir. İi aşamadan oluşan bu araştırmada ilk önce Okul Yönetişimi Ölçeğinin (OYÖ) geçerlik ve güvenirlik çalışmaları yapılmıştr. İkinci aşamada ise katılımcıların okul yönetişimini benimseme düzeyinin görev, cinsiyet ve kıdem değişkenleri bakımından istatistiksel açıdan anlamlı fark gösterip göstermediği araştrılmıştr. İlk grupta yer almayan ikinci gruptaki katılımcılara OYÖ’nün geçerlik ve güvenirliği sağlanmış son hali uygulanmıştir.

Bu amaç doğrultusunda aşağıdaki sorulara yanıt aranmıştır;

1. OYÖ’nün geçerlik ve güvenirlik düzeyi nedir?

2. Okul müdürü, öğretmen ve diğer okul personelinin okul yönetişimi algısı görev, cinsiyet ve kıdem değişkenleri bakımından anlamlı bir şekilde farklılaşmakta mıdır?

\section{Yöntem}

Yönetici, öğretmen ve okuldaki diğer personelin okul yönetişimini benimseme düzeyini belirlemek üzere geçerli ve güvenilir bir ölçme aracı geliştirmeyi ve katılımcıların okul yönetişimi benimseme düzeylerinin görev, cinsiyet ve kıdem değişkenleri bakımından anlamlı bir farklılık gösterip göstermediğini inceleyen bu araştırma, nicel araştırma yöntemlerinden genel tarama desenine örnektir

\section{Çalışma Grubu}

Araştırmanın iki çalışma grubu bulunmaktadır. OYÖ'nün geliştirilmesi kapsamında geçerlik ve güvenirlik çalışmalarının yapıldığı birinci çalışma grubunu 2015-2016 eğitim-öğretim yılında, Aksaray ilindeki kamu okullarında görev yapan ve uygun örnekleme ile seçilen 217 yönetici, öğretmen ve diğer personel oluşturmaktadır. Kattımcıların \% 66,3'ü erkek ( $n=144), \% 33,7^{\prime}$ ü kadındır ( $\left.n=73\right)$. Bununla birlikte katilımcıların \%25, 81'i $(n=56)$ yönetici, \%60,36'sı ( $\left.n=131\right)$ öğretmen ve $\% 13,83^{\prime} u ̈$ ( $\left.n=30\right)$ ise diğer personeldir.

Araştırmanın ikinci çalışma grubunu ise 322 kişi oluşturmaktadır. Bu kişiler, ilk çalışma grubunda yer almayan kişilerden oluşmaktadır. i̇kinci gruptaki kathlımcıların 124'si kadın $(\% 38,4)$ ve 198 'sı $(\% 61,6)$ erkektir. Kathlımııların 71'i yönetici (\%21.7), 211'i öğretmen (\%66,4) ve 40' (\%11,9) diğer personeldir. Diğer yandan katılımcıların 45'i 1-5 yıl (\%13,7), 40'। 6-10 yıl (\%12,1), 66'sı 11-15 yıl (\%20,2), 85'i, 16-20 yıl (\%26,4) ve 86'sı 21 yıl ve üzeri $(\% 26,7)$ mesleki kıdeme sahiptir.

\section{Veri Toplama Aracı}

OYÖ'nün geliştirilmesi kapsamında öncelikle yönetişim ile ilgili alan yazın taranmış ve incelenmiş, konuyla ilgili çalışmalar toplanarak yönetişim ve okulda yönetişime ilişkin genel bir kuramsal çerçeve oluşturulmuştur. Bu incelemeler sonunda yönetişimin adalet, işbirliği, şeffaflık ve katılım temel bileşenlerinin olduğu görülmüş ve bu doğrultuda eğitim ve eğitim örgütleri ile ilgili olabileceği düşünülen kuramsal bilgiler derlenmiş, ilgili alan yazın ve ölçme araçlarındaki benzer ifadelerden yararlanılmıştır (Arnott, 2000; Lewis ve Petterson, 2009; Yüksel, 2000; Toksöz, 2008; Tekeli, 1996; Stoker, 2004). Doğrudan alınan veya revize edilen madde bulunmamaktadır. Ayrıca ilk ve ortaöğretimde görev yapan beş kişilik bir öğretmen grubuyla görüşülerek yönetişim ile ilgili görüşler elde edilmeye çalışılmıştr. Ardından alanya- 
zın taraması ve görüşme sonrası okul yönetişimini yansıtacağı varsayılan 60 maddelik madde havuzu oluşturulmuştur. Taslak formun kapsam geçerliği, dil ve ifade bakımından incelenmesi için eğitim yönetimi, ölçme ve değerlendirme alanlarından yedi uzmanın görüşüne başvurulmuştur. Uzmanlar tarafindan kapsam geçerliğini sağlamadığı ve çalışmanın amacına hizmet etmediği belirtilen maddeler ölçekten çıkarılmıştır. 42 madde haline getirilen ölçekteki ifadeler düzenlenerek birinci çalışma grubuna uygulanmıştı. OYÖ de yer alan her bir maddeye verilecek tepkiler, "(1) Hiç Katılmıyorum (2) Az Kathlıyorum (3) Orta Derecede Katılıyorum (4) Çok Katılıyorum (5)Tam Katılıyorum" şeklinde derecelendirilmiştir. Buna göre ölçekten elde edilen daha yüksek puanlar, okul yönetişiminin benimsenme düzeyinin daha yüksek olduğunu göstermektedir.

OYÖ’nün "Adalet ve Şeffaflı" alt boyutunda 'Bu okulda, okul yönetimi herkese adil davranır' ve 'Bu okulun bütçesinin nerelerde kullanıldığı, okul çalışanlarının denetimine açıktı', "işbirliği ve Katılım" alt boyutunda 'Bu okulda çalışanlar arasında birliktelik ve birlikte hareket etme duygusu hakimdir' ve 'Bu okulda okul yöneticileri karar alırken çalışanlara danışır', "Çevre ile iliş̧kiler" alt boyutunda 'Okul bölgesinde yer alan STK'lar (vakıf, dernek gibi) okul yönetimi ile işbirliği yapmalıdır' gibi maddeler yer almaktadır.

\section{Verilerin Analizi}

Kapsam geçerliliği çalışmalarından sonra ölçeğin yapı geçerliğini test etmek amacıyla açımlayıcı faktör analizi; güvenirliğini test etmek amacıyla da Cronbach's alfa iç tutarlılık katsayısı hesaplanmıştır. İkinci araştırma sorusuna yanıt verebilmek için verilerin analizinde aritmetik ortalama, standart sapma değerleri gibi betimsel istatistiklerden ve parametrik (Bağımsız T-Testi ve ANOVA) testlerden yararlanılmıştr. Yönetici, öğretmen ve okuldaki diğer personelin okul yönetişimine ilişkin görüşlerinin cinsiyet değişkenine göre anlamlı biçimde farklılaşıp farklılaşmadığı t-testi; kıdem ve görev değişkenlerine göre farklılaşma durumuna ise tek yönlü varyans analizi (ANOVA) ile bakılmıştır.

\section{Bulgular}

\section{Okul Yönetişimi Ölçeğinin (OYÖ) Yapı Geçerliliğine iliş̧kin Bulgular}

OYÖ’nün geçerliği geçerlik türlerinden birisi olan yapı geçerliği ile analiz edilmiştir. OYÖ’nün faktör yapısı önce AFA ile incelenmiş, daha sonra elde edilen faktör yapısının doğrulamak amacıyla yeni bir örneklem üzerinde DFA yapılmıştır.

Açımlayıcı Faktör Analizi (AFA): Araştırmanın birinci aşamasında OYÖ’nün yapı geçerliğini ve faktör yapısını incelemek amacıyla AFA, faktörleştirme tekniği olarak ise temel bileşenler analizi kullanılmıştr. OYÖ'nün KMO değeri 0.968 ve Bartlett testi sonucunun anlamlı $(p<.000)$ olduğu görülmüştür. Dolayısıyla veri setinin AFA için mükemmel derecede uygunluk gösterdiği sonucuna varılmıştır (Büyüköztürk, 2011; Tabachnick ve Fidel, 2007). Yorumlamada kolaylık sağlamak amacıyla varimax dik döndürme kullanılmıştır. Madde toplam korelasyon sınırı 0.45 ve üzeri olarak kabul edilmiş ve bu değer altındaki altı madde ölçekten çıkarılmıştır. (Büyüköztürk, 2011). Ölçekte yer alan maddelerden 1, 2, 3, 4, $5,6,7,8,9,10,11,12,13,14$ ve 15. maddeler, "adalet ve şeffaflık", 17, 18, 19, 20, 21, 22, 23, 24, 25, 26, 27, 28, 29, 30 ve 31. maddeler "işbirliği ve katılım", 32, 33, 34, 35, 36 ve 37. maddeler ise "çevre ile ilişkiler", boyutu olarak adlandırılmıştır.

36 madde ve üç alt boyuttan oluşan ölçeğe ait boyutlar, faktör yük değerleri, açıkladığı varyans ve Cronbach alfa değerleri Tablo 1' de sunulmuştur.

Tablo 1. Ölçekteki Faktörler, Faktör Yük değerleri, Açıkladıkları Varyans Yüzdeleri, Madde Toplam Korelasyonları ve Cronbach Alfa Değerleri

\begin{tabular}{ccccc}
\hline Madde No & $\begin{array}{c}\text { F1 } \\
\text { Adalet ve şeffaflık }\end{array}$ & $\begin{array}{c}\text { F2 } \\
\text { İşbirliği ve katılım }\end{array}$ & $\begin{array}{c}\text { F3 Çevre ile ilişkiler } \\
\text { Kadde Toplam }\end{array}$ & $\begin{array}{c}\text { Ortak Faktör } \\
\text { Varyansı }\end{array}$ \\
\hline 1 & .612 & .636 & .502 \\
2 & .613 & .692 & .530 \\
3 & .669 & .740 & .606 \\
4 & .697 & .780 & .657 \\
5 & .581 & .700 & .538 \\
6 & .788 & .834 & .762 \\
7 & .758 & .811 & .723 \\
9 & .676 & .774 & .648 \\
\hline
\end{tabular}




\begin{tabular}{|c|c|c|c|c|c|}
\hline Madde No & $\begin{array}{c}\text { F1 } \\
\text { Adalet ve şeffaflık }\end{array}$ & $\begin{array}{c}\text { F2 } \\
\text { İşbirliği ve katılım }\end{array}$ & $\begin{array}{c}\text { F3 } \\
\text { Çevre ile ilişkiler }\end{array}$ & $\begin{array}{l}\text { Madde Toplam } \\
\text { Korelasyonu }\end{array}$ & $\begin{array}{c}\text { Ortak Faktör } \\
\text { Varyansı }\end{array}$ \\
\hline 10 & .768 & & & .875 & .810 \\
\hline 11 & .790 & & & .876 & .818 \\
\hline 12 & .724 & & & .790 & .697 \\
\hline 13 & .794 & & & .866 & .797 \\
\hline 14 & .656 & & & .811 & .713 \\
\hline 15 & .657 & & & .835 & .755 \\
\hline 17 & & .626 & & .733 & .593 \\
\hline 18 & & .632 & & .731 & .592 \\
\hline 19 & & .665 & & .770 & .658 \\
\hline 20 & & .673 & & .807 & .697 \\
\hline 21 & & .571 & & .645 & .461 \\
\hline 22 & & .644 & & .812 & .707 \\
\hline 23 & & .610 & & .720 & .577 \\
\hline 24 & & .733 & & .817 & .721 \\
\hline 25 & & .742 & & .800 & .718 \\
\hline 26 & & .649 & & .734 & .604 \\
\hline 27 & & .700 & & .793 & .682 \\
\hline 28 & & .710 & & .817 & .713 \\
\hline 29 & & .745 & & .862 & .788 \\
\hline 30 & & .653 & & .842 & .749 \\
\hline 31 & & .619 & & .736 & .594 \\
\hline 32 & & & .590 & .561 & .423 \\
\hline 33 & & & .757 & .694 & .613 \\
\hline 34 & & & .837 & .803 & .778 \\
\hline 35 & & & .855 & .824 & .821 \\
\hline 36 & & & .794 & .769 & .724 \\
\hline 37 & & & .794 & .772 & .740 \\
\hline Açıklanan Varyans & $\% 27,14$ & $\% 25,52$ & $\% 14,38$ & & \\
\hline Açıklanan toplam varyans & $\%$ 67,04 & & & & \\
\hline Cronbach Alfa & .963 & .962 & .885 & & \\
\hline
\end{tabular}

Tablo 1 incelendiğinde OYÖ’nün “Adalet ve Şeffaflı”" boyutunda yer alan faktör yük değerlerinin .581 ile .794 arasında değiştiği ve varyansın \%27, 14 açıklama oranına sahip olduğu görülmektedir. Bu boyutun iç tutarlılık katsayısı .963 olarak hesaplanmıştr. OYÖ' nün "işbirliği ve katılım" boyutunda ise faktör yük değerlerinin .571 ile .745 arasında değiştiği ve toplam varyansın \%25,52'sini açıkladığı görülmektedir. Bu boyutun Cronbach alfa güvenirlik katsayısı 962 olarak hesaplanmıştr. Son olarak "çevre ile ilişkiler" boyutundaki faktör yük değerlerinin .590 ile .794 arasında değiştiği ve toplam varyansın \%14, 38 ini açıkladığı görülmektedir. Bu boyutun iç tutarlılık katsayısı .885 olarak hesaplanmıştır.

Doğrulayııı Faktör Analizi (DFA): OYÖ’nün AFA ile elde edilen üç boyutlu yapısının doğrulanması amacıyla 322 kişilik yeni bir grup üzerinde DFA yapılmıştır. Yapılan analizde elde edilen modelin uyum indeksleri incelenmiş ve Ki-Kare değerinin $\left(X^{2}=1763,27, s d=588, p=0.00\right)$ anlamlı olduğu görülmüştür. Uyum indeksi değerleri ise RMSEA=.078, NFI= .97, $\mathrm{CFI}=.98, \mathrm{IFI}=.98, \mathrm{GFI}=.76$ ve $\mathrm{SRMR}=.049$ olarak hesaplanmıştr. Bu uyum indeksi değerleri ölçeğin AFA ile elde edilen üç boyutlu yapısını doğrulamaktadır.

Katılımcıların okul yönetişimini benimseme düzeyinin çeşitli demografik değişkenler bakımından incelenmesine ilişkin bulgular

Araştırmanın ikinci aşamasında yönetici, öğretmen ve diğer personelin okulda yönetişimi benimseme düzeyi çeşitli demografik değişkenlere dayalı olarak incelenmiştir.

Yönetici, öğretmen ve okuldaki diğer personelin okul yönetişimini benimseme düzeyinin görev değişkenine göre farklılık gösterip göstermediğini belirlemek üzere yapılan tek yönlü varyans analizi sonuçları Tablo 3'te verilmiştir. 
Tablo 3. Okul Yönetişimini Benimseme Düzeyinin Görev Değişkenine Göre ANOVA Sonuçları

\begin{tabular}{llccccccc}
\hline Boyutlar & Görev & $\mathrm{n}$ & Ort & Ss & $\mathrm{F}$ & $\mathrm{p}$ & Farkın Kaynağı \\
\hline \multirow{4}{*}{ Adalet ve şeffaflık } & Okul Yöneticisi & 71 & 4.13 &, 78 & & & \\
& Öğretmen & 211 & 3,86 &, 85 & 3,15 & $.04^{*}$ & Okul Yöneticisi-Öğretmen \\
& Diğer personel & 40 & 4,08 &, 82 & & & \\
\hline \multirow{3}{*}{ İşbirliği ve katılım } & Okul Yöneticisi & 71 & 4,03 &, 76 & & & \\
& Öğretmen & 211 & 3,86 & .82 & 1,34 & .26 & ----- \\
& Diğer personel & 40 & 4 & .90 & & & \\
\multirow{3}{*}{ Çevre ile ilişkiler } & Okul Yöneticisi & 71 & 4,22 & .74 & & & \\
& Öğretmen & 211 & 4,05 & .82 & 1,17 & \multirow{2}{*}{, 31} & \\
& Diğer personel & 40 & 4,08 & .85 & & & \\
$*^{*} p<.05$ & & & & & & &
\end{tabular}

Tablo 3'ten de görüleceği üzere katlımcıların "adalet ve şeffaflık" boyutunda okul yönetişimini benimseme düzeyleri görev değişkenine göre istatistiksel olarak anlamlı şekilde farklılaşmaktadır $(F=3,15, p<.05)$. Farkın hangi gruplar arasında olduğunu belirlemek amacıyla yapılan LSD testi sonuçlarına göre okul yöneticilerinin okul yönetişimini benimseme düzeyleri $($ Ort. $=4,13)$, öğretmenlere $(O r t .=3,86)$ göre daha yüksektir. Katılımcıların OYÖ’nün “işbirliği ve katllım” $(F=$ $1.34, p>.05)$ ile "çevre Ile ilişkiler" $(F=1.17, p>.05)$ boyutlarına ilişkin görüşleri arasında istatistiksel olarak anlamlı bir fark yoktur. Dolayısı ile bu boyutlarda paydaşların okul yönetişimini benimseme düzeyinin benzer olduğu söylenebilir.

Yönetici, öğretmen ve okuldaki diğer personelin okul yönetişimini benimseme düzeyinin cinsiyete göre farklılık gösterip göstermediğini incelemek amacıyla faktörlerden elde edilen puanlar "ilişkisiz örneklemler için t-testi" ile analiz edilmiş, sonuçlar Tablo 4'de verilmiştir.

Tablo 4. Yöneticilerin, Öğretmenlerin ve Diğer Personelin Okul Yönetişimini Benimseme Düzeylerinin Cinsiyet Değişkenine Göre Farklılaşma Durumu (T-Testi Sonuçları)

\begin{tabular}{|c|c|c|c|c|c|c|c|}
\hline Boyutlar & Cinsiyet & $\mathrm{n}$ & Ort. & Ss & sd & $\mathrm{t}$ & $\mathrm{p}$ \\
\hline \multirow{2}{*}{ Adalet ve şeffaflık } & Kadın & 123 & 3.92 & ,87 & \multirow{2}{*}{316} & \multirow{2}{*}{,- 551} & \multirow{2}{*}{,582 } \\
\hline & Erkek & 199 & 3.97 & ,84 & & & \\
\hline \multirow{2}{*}{ İşbirliği ve katılım } & Kadın & 123 & 3,93 & ,81 & \multirow{2}{*}{316} & \multirow{2}{*}{ 156 } & \multirow{2}{*}{,876 } \\
\hline & Erkek & 199 & 3,91 & ,83 & & & \\
\hline \multirow{2}{*}{ Çevre ile ilişkiler } & Kadın & 123 & 3,97 & ,93 & \multirow{2}{*}{316} & \multirow{2}{*}{$-2,159$} & \multirow{2}{*}{, $032^{*}$} \\
\hline & Erkek & 199 & 4,17 & 71 & & & \\
\hline
\end{tabular}

Tablo 4'de görüldüğü gibi katılımcıların okul yönetişimini benimseme düzeyleri cinsiyet değişkenine göre "adalet ve şeffaflık" ( $t_{(316)}=2.15 p>$.05) ve "işbirliği ve katılım" $\left(t_{(316)}=2.15 ; p>.05\right)$ boyutlarında anlamlı bir farklılık göstermezken, "çevre ile ilişkiler" boyutunda istatistiksel olarak anlamlı farklılık göstermektedir $\left(t_{(316)} 2.15 ; p<.05\right)$. Buna göre erkek katılımcıların (Ort. 4.17) okulda yönetişimi benimseme düzeyleri kadın katlımcılara göre (Ort. 3.97) daha yüksektir.

Yönetici, öğretmen ve diğer personelin okul yönetişimini benimseme düzeylerinin kıdem değişkenine göre farklılık gösterip göstermediğini belirlemek üzere yapılan tek yönlü varyans analizi sonuçları Tablo 5'de verilmiştir.

Tablo 5. Katılımcıların Okul Yönetişimini Benimseme Düzeyinin Kıdem Değişkenine Göre ANOVA Sonuçları

\begin{tabular}{lccccccc}
\hline Boyutlar & Kıdem & $\mathrm{n}$ & Ort & Ss & $\mathrm{F}$ & $\mathrm{p}$ & Farkın Kaynağı \\
\hline & $1-5$ & 44 & 4,16 &, 53 & & & \\
Adalet ve & $6-10$ & 39 & 3,83 &, 89 & & & \\
şeffaflık & $11-15$ & 65 & 3,86 &, 90 & 2.04 & .089 & - \\
& $16-20$ & 85 & 3,82 &, 93 & & \\
& $21+$ & 86 & 4,08 &, 82 & & \\
\hline
\end{tabular}




\begin{tabular}{lccccccc}
\hline Boyutlar & Kıdem & $\mathrm{n}$ & Ort & Ss & $\mathrm{F}$ & $\mathrm{p}$ & Farkın Kaynağı \\
\hline & $1-5$ & 44 & 4,11 &, 61 & & & \\
İşbirliği ve & $6-10$ & 39 & 3,83 &, 92 & & & \\
katılım & $11-15$ & 65 & 3,83 &, 85 & 1.39 & .236 & \\
& $16-20$ & 85 & 3,82 &, 88 & & \\
& $21+$ & 86 & 4,00 &, 77 & & \\
& $1-5$ & 44 & 4,06 &, 85 & & \\
Çevre ile & $6-10$ & 39 & 4,17 &, 70 & & \\
ilişkiler & $11-15$ & 65 & 4,07 &, 83 & .271 & & \\
& $16-20$ & 85 & 4,04 &, 85 & & \\
\end{tabular}

Tablo 5'den de görüleceği gibi katlımcıların okul yönetişimini benimseme düzeyleri OYÖ’nün tüm boyutlarında kıdem değişkeni bakımından anlamlı fark göstermemektedir $(p>.05)$. Dolayısıyla katılımcıların okul yönetişimini benimseme düzeyleri kıdem değişkenine göre benzerdir.

\section{Tartışma ve Sonuç}

Bu çalışmada okul yöneticisi, öğretmen ve diğer okul personelinin okul yönetişimini benimseme düzeyini belirlemeye dönük geçerli ve güvenilir bir ölçeğin geliştirilmesi amaçlanmıştı. Bu amaçla önce ilgili alan yazın taranmış, ardından madde havuzu oluşturulmuştur. Daha sonra uzman görüşlerine dayalı olarak bu maddeler üzerinde gerekli düzeltmeler yapılarak ölçek ön uygulama için hazır hale getirilmiştir.

İki aşamada yürütülen çalışmanın birinci aşamasında OYÖ’nün geçerlilik ve güvenirlik çalışmaları 217 yönetici, öğretmen ve diğer okul personelinden toplanan veriler üzerinde yürütülmüştür. Analizler sonucunda OYÖ’de yer alan boyutlar içerdikleri maddelere göre "Adalet ve Şeffafık", "işbirliği ve Katılım" ve "Çevre ile ilişkiler" olarak adlandırılmıştr. Boyutların adlandırılmasında ifadelerin benzerlikleri esas alınmıştı. Bu bulgulara dayalı olarak OYÖ’nün Türkiye'deki okullarda okul yöneticilerinin, öğretmenlerin ve okuldaki diğer personelin okul yönetişimini benimseme düzeyini belirlemeye elverişli, üç boyutlu ve 36 maddeden oluşan geçerli ve güvenilir bir ölçme aracı olarak kabul edilebilir.

Çalışmanın ikinci aşamasında, geçerlik ve güvenirliği sağlanmış OYÖ’nün farklı bir katılımcı grup üzerinde bazı demografik değişkenlere göre analizi yapılmıştr. 322 okul yöneticisi, öğretmen ve diğer okul personelinin okul yönetişimini benimseme düzeyi görev değişkeni bakımından incelendiğinde yöneticilerin, öğretmen ve diğer personele göre görece daha yüksek benimseme düzeyine sahip olduğu görülmüştür. Ortaya çıkan bu bulgu son dönemlerde kamu yönetimi alanında ortaya çıkan ve eğitim örgütleri özelinde de tartışılan yönetişim yaklaşımının okul çalışanları tarafindan kabul gördüğü (Halasz, 2003), okul yöneticileri tarafindan daha çok benimsendiği görüşünü desteklemektedir (Rhodes, 2007). Eğitim hizmetlerinin yürütüldüğü temel yönetsel birim olan okulların yöneticilerinin bir örgüt olarak okulun temel sorunlarını hızlı bir şekilde çözüme kavuşturma istekleri bu değişimi benimsemelerinin gerekçesi olabilir (Altrichter ve Maag Merki, 2010). Türkiye'deki alanyazına bakıldığında bu bulguyla benzerlik taşıyan çalışmaların olduğu görülmektedir. Örneğin Sabancı'ya (2009) göre yönetici, öğretmen ve velilerin tutumları çevre ile ilişkiler konusunda genel olarak olumludur ancak kendi içlerinde farklılıklar göstermektedir. Buna göre öğretmenler ile velilerin işbirliğine ilişkin puanları daha düşüktür. Sürücü (2011) çevre ile ilişkiler konusunda okul yöneticilerinin olumlu yüksek bir tutuma sahip olduklarını bulgulamıştır. Aslan ise (2016) çalışmasında yöneticilerin yönetişim algılarının öğretmenlerinkine göre yüksek olduğunu saptamıştr. Mevcut çalışmanın bu bulgusu Türkiye'de öğretmenlerin ve diğer okul personelin yönetimsel süreçlerde yer almak istememesi ve sorumluluk almaktan kaçınması ile açıklanabilir. Diğer yandan yöneticilerin örgütsel sistemi yaşatma ve örgütü hedeflerine ulaştırmada öğretmenlere göre daha fazla sorumluluk taşımaları da bu bulgunun sebebi olarak öne sürülebilir.

Araştırmada katılımcıların okul yönetişimini benimseme düzeyinin cinsiyet değişkeni bakımından farklılaşma durumuna bakılmış "çevre ile ilişkiler" boyutunda erkek çalışanlar lehine manidar bir farklıı̆ı̆ın olduğu görülmüştür. Alanyazında bu bulguyu destekleyen (Aslan, 2016; Yiğit, 2013) ve bu bulguyla çelişen (Izgar, 2015) sonuçlara sahip çalışmaların yanında, yönetişim algısının çalışanların cinsiyetine göre manidar bir şekilde farkılış̧madığını (Sanal, 2009; Subaş, 2010; Öztürk, 2015) ortaya koyan bulguların olduğu da görülmektedir. Izgar’a (2015) göre eğitim örgütlerinde kadın yöneticilerin yönetişim algılarının erkeklerinkine göre daha yüksek olması, son dönemlerde kamu sektöründe kadınlar lehine yapılan yasal değişikliklerin etkisinin bir sonucu olabilir. Mevcut çalışmada ise erkek ve kadın katlımcıların okulda 
yönetişimi benimseme düzeyi bir ve ikinci boyutlarda benzer iken, üçüncü boyutta erkekler lehine daha yüksektir. Bu durum geleneksel cinsiyet rolünün örgütlerdeki yansıması şeklinde değerlendirilebilir. Okulun çevreyle (STK'lar, farklı kamu kuruluşları, muhtarlar, belediyeler vs.) ilişkiler kurması konusunda kadınların erkeklere göre daha az benimseme düzeyine sahip olmaları Sosyal Rol Kuramı (Eagly, 1987) ile açıklanabilir. Bu kurama göre kadınların evdeki, erkeklerin ise evin dışındaki rolleri yerine getirmeleri beklenmektedir. Diğer yandan bu bulgu, geleneksel eril toplumlarda kadınlardan beklenen toplumsal rollerin örgütlere yansıması olarak da değerlendirilebilir. Şöyle ki, eril toplumlarda kadınların iş yaşamına girmiş olmalarına rağmen kendilerinden dış çevreye değil örgüt içindeki rollere odaklanmaları beklenmektedir (Hofstede ve Hofstede, 2005).

Araştırmanın bir diğer bulgusuna göre okul yönetişimini benimseme düzeyi katılımcıların kıdemi değişkenine göre anlamlı bir şekilde farklılaşmamaktadır. Başka bir deyişle farklı mesleki kıdemlere sahip olsalar da okul müdürü, öğretmen ve diğer personelin okul yönetişimini benimseme düzeyleri benzerdir. Bu konuda yapılan bazı çalışmaların bulgularının birbiriyle çeliştiği görülmektedir. Örneğin Bayraktar, Güven ve Temel (2016) okula katılım çalışmalarında görece daha düşük kıdeme sahip öğretmenlerin daha olumlu bir görüşe sahip olduklarını, bunun nedeni olarak da genç öğretmenlerin okula katılım çalışmaları hakkındaki bilgilerinin güncel olmasından kaynaklanabileceğini öne sürmüştür. Özdemir ve Bozkurt (2015) ise çalışmalarında MEB'in aşırı merkeziyetçi yönetsel yapısının getirdiği kırtasiyeciliğin sonucu olarak işlerin yavaş işlemesinin çalışanları yormuş olabileceği dolayısı ile kıdemi fazla olan okul çalışanlarının yönetişimi daha fazla benimsemiş olabileceğini öne sürmüştür.

Türkçe alanyazına bakıldığında eğitim örgütlerinde yönetişim algısına ilişkin yapılmış bir çalışmanın olmadığı görülmektedir. Gönüllülük esasına göre okul müdürü, öğretmen ve diğer okul personelleri ile yürütülen bu çalışmanın farklı illerde veya daha geniş örneklemler üzerinde yürütülmesi önerilebilir. Yönetişim; grupla karar alma, işbirliği, şeffaflık ve adalet gibi birçok bileşeni içermekte ve etkili bir yönetim tarzı oluşturmayı amaçlamaktadır. Dolayısı ile okul yönetişiminin ileriki aşamalarda adı geçen bileşenler göz önünde bulundurularak incelenmesi uygun olabilir. Ayrıca bu konuyla ilgili yapılacak araştırmaların nitel desenlerle de desteklenerek incelenmesinin konunun bütüncül açıdan derinliğine kavranmasına katkı sağlayabileceği düşünülmektedir.

\section{Kaynakça}

Altrichter, H., \& Maag Merki, K. (2010). Handbuch Neue Steuerung im Schulsystem. Wiesbaden: VS Verlag für Sozialwissenschaften.

Arnott M.A. (2000) Restructuring the Governance of Schools: The impact of managerialism on schools in Scotland and England, in Arnott M.A., Raab C.D. (Eds) The Governance of Schooling: Comparative studies of devolved management, London: Routledge.

Aslan, M.S. (2016). Özel ve Devlet Okullarinin Yönetişim Özelliklerine Sahip Olma Düzeyleri. Yayımlanmamış Yüksek lisans tezi. Harran üniversitesi.

Backmen, E. ve Trafford, B. (2007). Okulların Demokratik Yönetişimi. Strasbourg: Avrupa Konseyi Yayınları.

Bayraktar, V.,Güven, G.,Temel, Z.F.(2016). Okul öncesi kurumlarda görev yapan öğretmenlerin aile katılım çalışmalarına yönelik tutumlarının incelenmesi. Kastamonu Eğitim Dergisi, 24 (2), 755-770.

Bevir, M. (2013). Democratic governance, UK: Princeton Universty Press.

Bevir, M. and Rhodes, R. A.W. (2003) 'Searching for Civil Society: Changing Patterns of Governance in Britain', Public Administration, 81 (1), 41-62.

Bozkuş, B. (2009). Türk kamu yönetiminde yönetişim tartışmaları ve yönetişimin kamu yönetiminde uygulanabilirliği. Yüksek Lisans Tezi, Selçuk Üniversitesi Sosyal Bilimler Enstitüsü, Konya.

Bush, T., Heystek, J. (2003). School Governance in the New South Africa. Compare. 33 (2), 127-138.

Büyüköztürk, Ş. (2011). Sosyal bilimler için veri analizi el kitabı (11. baskı). Ankara: PegemA

Chhotray, V. ve Stoker, G. (2009). Governance theory and practice: A Cross Disciplinary Approach. Basingstoke: Palgrave.

Cooper, R. ( 1996). The post -modem state and the world order. London: Demos.

Darling-Hammond, L. \& Bullmaster, M. (1997). The changing social context of teaching in the United States, in: B. Biddle et al. (Eds) International Handbook of Teachers and Teaching. Dor- drecht: Kluwer Academic.

Eagly, A. (1987). Sex differences in social behavior: A social role interpretation. Hillsdale, NJ: Erlbaum.

Ensari, H. (1999). 21. yüzyıl okulları için toplam kalite yönetimi. (1. Basım). İstanbul. Sistem Yayıncılık.

Ergün,í. (2006). Yerel yönetimlerde yönetişim kavramı ve avrupa birliği ile kıyaslanması. Yayınlanmamış Yüksek Lisans Tezi, Dokuz Eylül Üniversitesi SBE, İzmir.

Frederickson, H.G. ve Kevin B. S.(2003), The public administration theory primer, Oxford: Westviev Press,

Frederickson, H. G. (1999). The repositioning of American public administration. PS: Political Science and Politics 32(4), $701-711$. 
Gül, İ. (2013). İlköğretim Okulu Yöneticilerinin Okul Çevre İlişkilerinin Geliştirilmesine Yönelik Görüşleri. Ondokuz Mayıs Üniversitesi Eğitim Fakültesi Dergisi, 32(1), 165-192.

Gündüz, Y. ve Balyer, A. (2013). “Gelecekte Okul Müdürlerinin Gerçekleştirmeleri Gereken Roller.” Anadolu Üniversitesi Sosyal Bilimler Dergisi, 13 (3).

Halász, G. (2003). Governing schools and education systems in the era of diversity. In A paper prepared for the 21st Session of the Standing Conference of European Ministers of Education on" Intercultural education: managing diversity, strengthening democracy"(Athens, Greece, 10-12 November 2003-Council of Europe).

Hodgson, G.M. (2001). Socio-economic Consequences of the Advance of Complexity and Knowledge. In OECD (ed.), The Creative Society of the 21st Century, 89-112. Paris: OECD

Hofstede, G. \& Hofstede, G. J. (2005). Cultures and organizations: software of the mind (Rev. 2nd ed.). New York: McGraw-Hill.

Karataş, I,H. (2013). Türk Eğitim Sisteminde Sivil Toplum Kuruluşlarının Konumları ve İşlevlerine Yönelik STK Yöneticilerinin Görüşleri. Elektronik Sosyal Bilimler Dergisi, 12 (45).

Kettl, D.F.(2002). The transformation of governance. public administration for twenty-first century america. The Johns Hopkins University Press, Baltimore.

Kooiman, J. (1993). Governance and governability: Using complexity, dynamics, and diversity. In J. Kooiman (Ed.), Modern governance. New government-society interactions (pp.35-50). London: Sage Publications.

Kooiman, J. (2003). Governing as governance. London: Sage.

Lewis, M., Petterson, G. (2009). Governance in education; raising performance. World Bank Documents.

Lunenburg, F. C. ve Ornstein, A. C. (2013). Eğitim yönetimi (Çev. G. Arastaman). Ankara: Nobel.

Memduhoğlu, H. B. (2011). “Liselerde Farklılıkların Yönetimi: Bireysel Tutumlar, Örgütsel Değerler ve Yönetsel Politikalar." Mersin Üniversitesi Eğitim Fakültesi Dergisi, 7 (2), 37-53.

Özer, A.(2015). 21. yüzyılda yönetim ve yöneticiler, Adalet Yayınları, Ankara

Özdemir, M. \& Bozkurt, S. (2015). Eğitim ve okul yöneticilerinin yeni-kamu işletmeciliği anlayışına ilişkin görüşlerinin incelenmesi. Marmara Üniversitesi Atatürk Eğitim Fakültesi Eğitim Bilimleri Dergisi. 42, 317-334.

Öztürk, M.F. (2015). Okul-çevre ilişkilerinin sınıf öğretmenlerinin görüşleri açısından değerlendirilmesi. Yayınlanmamış Yüksek Lisans Tezi. Niğde Üniversitesi.

Pierre, J., Peters, B.(2005) Governing Complex Societies Trajectories and Scenarios,Chippenham and Eastbourne: Palgrave Macmillan.

Rhodes, R. A. W. (2007). Understanding governance: Ten years on. Organization Studies, 25(8), 1243-1264.

Rhodes, R. A. (1997). Understanding governance: Policy networks, governance, reflexivity and accountability. Open University Press.

Rhodes, R. A. W. (1996). The new governance: governing without government. Political studies, 44(4), 652-667.

Sabancı, A. (2009). Türkiye'de Veli Katılımına İlişkin İlköğretim Okulu Yöneticilerinin, Öğretmenlerinin ve Öğrenci Velilerinin Görüşleri. Eğitim Araştirmaları Dergisi, 36.

Selwyn, N. (2016). There's so much data': Exploring the realities of data-based school governance. European Educational Research Journal. $15(1), 54-68$

Showunmi, V. (2013). Governing and governance in education: Introduction. Management in Education, 27(3), 83.

Smith, A.D. (1995). Nations and nationalism in the global era. Cambridge: Polity Press.

Smith, M. (1999) The core executive in britain, Basingstoke: Macmillan.

Sobacı, Z.M.(2007). Yönetişim kavramı ve Türkiye'de uygulanabilirliği üzerine değerlendirmeler. Yönetim Bilimleri Dergisi. 5 (1). $219-235$

Stoker, G. (2004) Transforming local governance: From thatcherism to new labour. Basingstoke: Palgrave.

Sürücü, G. (2011). Okul çevre ilişkilerinin okul yönetimine etkileri. Yayınlanmamış Yüksek Lisans Tezi, Trakya Üniversitesi.

Subaş, A. (2010). ilköğretim Okullarında Çalışan Sınıf ve Branş Öğretmenlerinin Öğrenen Örgütü (okulu) Algılamaları. Yayımlanmamış Yüksek Lisans Tezi, Marmara Üniversitesi Eğitim Bilimleri Enstitüsü, İstanbul.

Şanal, E. E. (2009). Beden Eğitimi ve Spor Yüksekokullarında Görevli Akademik Personelin Öğrenen Örgüt Kültürüne Illişkin Görüşleri. Yayımlanmamış Yüksek Lisans Tezi, Muğla Üniversitesi Sosyal Bilimleri Enstitüsü, Muğla.

Tabachnick, B.G., and L.S. Fidell. (2007). Using multivariate statistics. Boston: Pearson/Allyn \& Bacon.

Toksöz, F. (2008), İyi yönetişim el kitabı, TESEV Yayınları, İstanbul.

Tekeli, İ. (1996). Yönetim Kavramı Yanısıra Yönetişim Kavramının Gelişmesinin Nedenleri Üzerine, Sosyal Demokrat Değişim, 3: $45-54$.

Ünver, G.B., Dikbayır, A., Yurdakul, B.(2015). Kesintili zorunlu eğitim ilkokul birinci sınıf uygulamalarının incelenmesi. Kastamonu Eğitim Dergisi.23 (4), 1647-1664.

Yolcu, H. (2010). Neo-Liberal Dönüşümün Yaşandiği Ülkelerde Yerelleşme ve Okul Özerkliği Uygulamalari. Zonguldak Karaelmas University Journal of Social Sciences, 6(12). 
Yolcu, H. (2011). Türkiye'de eğitimde yerelleşme ve ailelerin okul yönetimine katılımının güçlendirilmesi: Değişen ne. Kuram ve Uygulamada Eğitim Bilimleri, 11(3), 1229-1251.

Yüksel, M. (2000). Yönetişim ( Governance) Kavramı Üzerine. Ankara Barosu Dergisi, 3, 145-160 